\title{
Pemahaman Konsep Hubungan antara Arah Gaya, Kecepatan dan Percepatan dalam Satu Dimensi pada Mahasiswa Calon Guru Fisika FKIP Universitas Tadulako
}

\author{
Hasnawiyah, Unggul Wahyono dan Darsikin \\ E-mail: Hasnawiyahphysics@yahoo.co.id \\ Prodi Pendidikan Fisika FKIP Universitas Tadulako \\ JI. Soekarno Hatta KM. 9 Kampus Bumi Tadulako Tondo Palu - Sulawesi Tengah
}

\begin{abstract}
Abstrak - Penelitian ini bertujuan untuk menganalisis pemahaman konsep mahasiswa tentang hubungan arah gaya, kecepatan dan percepatan dalam satu dimensi pada materi mekanika. Dalam penelitian ini dipilih subjek penelitian 100 mahasiswa, 50 mahasiswa semester akhir (angkatan 2010) dan 50 mahasiswa baru (angkatan 2013). Data dikumpulkan melalui pemberian tes FVA yaitu tes hubungan gaya, kecepatan dan percepatan dalam bentuk pilihan ganda beralasan dan wawancara dengan 12 responden yang dipilih berdasarkan perolehan skor tertinggi dan skor terendah dari tiap-tiap angkatan. Data penelitian dianalisis dengan pendekatan kualitatif-deskriptif. Hasil penelitian menunjukkan pemahaman mahasiswa mengenai kecepatan akan selalu searah dengan percepatan. Jika sebuah benda dipengaruhi oleh dua buah gaya yang sama besar dan berlawanan arah maka benda tidak dapat bergerak. Arah percepatan akan selalu searah dengan gerak benda. Ketika benda mengalami percepatan maka tidak bisa kecepatannya berkurang. Berdasarkan hasil wawancara diketahui bahwa salah satu penyebab kurangnya pemahaman mahasiswa karena mereka kurang belajar konsep. Hal ini menunjukkan bahwa cara belajar mahasiswa lebih ke matematis dengan contoh-contoh yang ada.
\end{abstract}

Kata Kunci: Pemahaman konsep, gaya, kecepatan, percepatan, satu dimensi

\section{PENDAHULUAN}

Fisika merupakan salah satu mata pelajaran yang dianggap sulit, mendengar kata fisika yang terbayang adalah sederetan rumus. Hal ini dikarenakan, pada saat belajar di sekolah peserta didik hanya di ajarkan rumus-rumus tanpa memahami konsep materi itu sendiri. Peserta didik seperti hanya diajari rumus dan contoh pemakaiannya dalam pengerjaan soal. Akibatnya peserta didik seringkali hanya bisa menjawab soal-soal fisika yang sudah pernah ada contohnya, namun kesulitan menyelesaikan soal-soal lain yang belum ada contoh penyelesaiannya walaupun sebenarnya mempunyai konsep yang sama. Sebagai contoh sederhana, yaitu konsep percepatan. Untuk memahami tentang percepatan tentu kita perlu tahu tentang kecepatan.

Sutopo [1] menyatakan untuk memahami dengan baik ide-ide mekanika, siswa (mahasiswa) perlu memiliki pemahaman yang kokoh tentang konsep-konsep kinematika seperti posisi, kecepatan, dan percepatan baik secara kualitatif-konseptual maupun secara kuantitatif-operasional. Tetapi banyak penelitian yang mengungkapkan kurangnya pemahaman mahasiswa mengenai konsepkonsep tersebut.
Rosenblatt dan Heckler [2] menyelidiki pemahaman siswa tentang hubungan antara resultan arah gaya, kecepatan, dan percepatan. Mereka menemukan bahwa sebagian besar siswa mengalami miskonsepsi. Pendrill [3] menemukan kesulitan siswa dalam memahami gaya dan percepatan. Penyelidikan pertama yang dilakukan pada kelompok mahasiswa dengan pemahaman yang baik yang diukur menggunakan tes Force Concep Inventory (FCI). Ditemukan bahwa banyak dari mereka mengalami kesulitan dalam menerapkan hukum Newton untuk gerak melingkar dalam bidang vertikal. Pada kelompok wawancara dengan beberapa siswa tentang konsep dari percepatan menunjukkan hubungan yang sangat lemah terhadap gaya.

Pemahaman konsep sangat penting dikuasai seorang mahasiswa calon guru. Apalagi mahasiswa yang akan melakukan Praktek Pengalaman lapangan (PPL). Mahasiswa yang tidak memahami konsep akan mengajarkan konsep yang salah atau tidak sesuai dengan konsep ilmuan pada peserta didiknya. Meskipun peserta didik mempelajari konsep yang benar, tetapi kemungkinan peserta didik akan tetap mengingat konsep yang telah diajarkan oleh guru. Oleh karena itu, pemahaman mahasiswa sebagai calon guru sangat penting dalam 
ISSN 23383240

mengajar. Tetapi pada kenyataannnya selain banyak ditemukan di negara lain ternyata di Indonesia juga banyak hasil penelitian yang menemukan bahwa masih banyaknya mahasiswa yang kurang memahami konsep atau mengalami miskonsepsi.

Penelitian dari Pujianto [4] yang dilakukan pada siswa menunjukkan bahwa konsepsi yang dialami siswa kelas X SMA Negeri 6 Palu pada konsep kinematika gerak lurus adalah sebesar $50,00 \%$ mengarah ke miskonsepsi dan siswa dengan pemahaman konsep kinematika gerak lurus yang baik hanya sebesar $21,67 \%$. Berdasarkan latar belakang di atas maka penelitian ini bermaksud untuk mendeskripsikan dan menganalisis pemahaman mahasiswa terhadap hubungan antara arah gaya, kecepatan dan percepatan dalam satu dimensi pada mahasiswa semester akhir (angkatan 2010) yang telah memprogram mata kuliah mekanika dan mahasiswa baru (angkatan 2013) program studi pendidikan fisika Universitas Tadulako.

\section{METODOLOGI PENELITIAN}

Penelitian ini merupakan penelitian kualitatif dengan menggunakan pendekatan deskriptif kualitatif. Penelitian ini dilaksanakan di salah satu perguruan tinggi yang ada di Kota Palu dengan subjek sebanyak 100 Mahasiswa, 50 mahasiswa semester akhir (angkatan 2010) dan 50 mahasiswa baru (angkatan 2013).

TABEL I PERSENTASE PEMILIHAN JAWABAN MAHASISWA TIAP OPTION. (X) TIDAK MENJAWAB, JAWABAN YANG BENAR ADALAH YANG DICETAK TEBAL DAN SOAL NOMOR 9 A, B, DAN D PILIHAN YANG BENAR.

\begin{tabular}{|c|c|c|c|c|c|c|c|c|c|c|c|c|c|c|c|c|c|}
\hline \multirow{3}{*}{$\begin{array}{l}\text { No. } \\
\text { Soal }\end{array}$} & \multirow{3}{*}{ Tipe Soal } & \multicolumn{8}{|c|}{ Mahasiswa Semester Akhir (Angkatan 2010) } & \multicolumn{8}{|c|}{ Mahasiswa Baru (Angkatan 2013) } \\
\hline & & \multicolumn{8}{|c|}{ Option \% } & \multicolumn{8}{|c|}{ Option \% } \\
\hline & & $\mathbf{A}$ & B & C & D & $\mathbf{E}$ & $\mathbf{F}$ & $\mathbf{G}$ & $\mathbf{x}$ & A & B & $\mathbf{C}$ & D & $\mathbf{E}$ & $\mathbf{F}$ & G & $\mathbf{x}$ \\
\hline 1 & $\vec{v} \longrightarrow \vec{F}$ & 80 & 6 & 6 & 0 & 4 & 2 & & 2 & 76 & 2 & 2 & 12 & 2 & 6 & & 0 \\
\hline 2 & $\vec{v}, \Delta \vec{v} \longrightarrow \vec{a}$ & 60 & 0 & 16 & 8 & 14 & 2 & & 0 & 72 & 2 & 2 & 10 & 14 & 0 & & 0 \\
\hline 3 & $\vec{F}=0 \longrightarrow \vec{v}$ & 2 & 12 & 68 & 12 & 4 & & & 2 & 4 & 6 & 54 & 32 & 4 & & & 0 \\
\hline 4 & $\vec{a} \longrightarrow \vec{v}$ & 56 & 2 & 10 & 22 & 2 & 6 & & 2 & 42 & 8 & 8 & 32 & 4 & 6 & & 0 \\
\hline 5 & $\vec{F} \longrightarrow \vec{a}$ & $32 / 4 *$ & 16 & 24 & 12 & 8 & 4 & & 4 & 44 & 12 & 10 & 8 & 18 & 4 & & 4 \\
\hline 6 & $\vec{v} \longrightarrow \vec{a}$ & 48 & 2 & 22 & 2 & 20 & $4 / 2 *$ & & 2 & 70 & 2 & 8 & 2 & 14 & 2 & & 2 \\
\hline 7 & $\vec{v}, \Delta \vec{v} \longrightarrow \vec{F}$ & 48 & $16 / 4 *$ & 22 & 4 & 0 & 0 & 4 & 6 & 32 & 22 & 10 & 6 & 8 & 2 & 12 & 8 \\
\hline 8 & $\vec{a} \longrightarrow \vec{v}, \Delta \vec{v}$ & 54 & 10 & 0 & 28 & 0 & 6 & & 2 & 40 & 10 & 2 & 44 & 4 & 0 & & 0 \\
\hline 9 & $\begin{array}{l}\vec{v} \longrightarrow \vec{F}- \\
\text { List }\end{array}$ & $86 / 4 *$ & $80 / 4 *$ & 50 & $72 / 4 *$ & 8 & & & 2 & 58 & 50 & 48 & 68 & 18 & & & 4 \\
\hline 10 & $\vec{F} \longrightarrow \vec{v}$ & 66 & 10 & 6 & 10 & 4 & 4 & & 0 & 50 & 6 & 0 & 22 & 14 & 2 & & 6 \\
\hline 11 & $\vec{a} \longrightarrow \vec{F}$ & $70 / 2 *$ & 8 & 12 & 4 & 4 & 2 & & 0 & 74 & 4 & 0 & 6 & 8 & 4 & & 4 \\
\hline 12 & $\vec{v}=0 \longrightarrow \vec{F}$ & 2 & $48 / 2 *$ & 28 & 10 & 0 & 0 & 8 & 4 & 16 & $46 / 4 *$ & 16 & 6 & 0 & 0 & 8 & 8 \\
\hline 13 & $\vec{a} \longrightarrow \vec{v}$ & 40 & 8 & 4 & 28 & 6 & 2 & 10 & 2 & 36 & 20 & 10 & 24 & 4 & 2 & 4 & 0 \\
\hline 14 & $\vec{F} \longrightarrow \vec{v}$ & 20 & 64 & 2 & 8 & 4 & 0 & & 2 & 10 & 54 & 4 & 22 & 4 & 2 & & 4 \\
\hline
\end{tabular}

Responden yang diwawancarai sebanyak 12 mahasiswa untuk menelusuri pemahaman konsep mahasiswa tentang arah gaya, kecepatan dan percepatan dalam satu dimensi.

Instrument yang digunakan pada penelitian ini tes FVA dari Rosemblatt dan Heckler [2] dengan jenis soal pilihan ganda beralasan. Dalam penelitian ini menggunakan metode analisis deskriptif, analisa data terhadap hasil penelitian meliputi:

a. Analisis terhadap distribusi

pemilihan option

Untuk menghitung presentase pemilihan tiap option per butir soal digunakan persamaan:

$$
A=\frac{x}{n} \times 100 \%
$$

dengan

$X$ : Persentase pemilihan setiap option

$n_{1}$ : Jumlah siswa yang memilih option

$n$ : Banyaknya peserta tes

b. Analisis alasan dari pilihan jawaban yang dipilih

c. Analisis terhadap hasil wawancara untuk mengetahui pemahaman konsep mahasiswa.

\section{HASIL DAN PEMBAHASAN}

Hasil penelitian yang diperoleh dalam penelitian ini dapat dilihat pada Tabel $\mathrm{I}$. 
ISSN 23383240

\begin{tabular}{|c|c|c|c|c|c|c|c|c|c|c|c|c|c|c|c|}
\hline 15 & $\vec{a} \rightarrow \Delta \vec{v}$ & 38 & 18 & 42 & & & & 2 & 40 & 8 & 50 & & & & 2 \\
\hline 16 & $\vec{v} \longrightarrow \vec{F}$ & 62 & 10 & 18 & 4 & 2 & 2 & 2 & 54 & 6 & 10 & 12 & 6 & 8 & 4 \\
\hline 17 & $\vec{v} \longrightarrow \vec{a}$ & 42 & 4 & 24 & 4 & 8 & $14 / 2 *$ & 4 & 58 & 8 & 14 & 10 & 6 & 2 & 2 \\
\hline
\end{tabular}

* TIDAK DISERTAI ALASAN

Hasil penelitian yang menggunakan tes FVA yang terdiri dari 17 item soal terbagi dalam beberapa konsep hubungan antara arah gaya, kecepatan dan percepatan seperti pada tabel II.

\begin{tabular}{|c|c|c|}
\hline No & $\begin{array}{c}\text { Hubungan Antar Konsep dan } \\
\text { Tipe Soal }\end{array}$ & $\begin{array}{c}\text { Nomor } \\
\text { Pertanyaan }\end{array}$ \\
\hline 1. & $\begin{array}{l}\text { Hubungan Antara Arah } \\
\text { Kecepatan dan Percepatan } \\
\vec{v}, \Delta \vec{v} \rightarrow \vec{a}_{1} \\
\vec{v} \longrightarrow \vec{a}_{1}\end{array}$ & $\begin{array}{l}2 \\
6,17\end{array}$ \\
\hline 2. & $\begin{array}{l}\text { Hubungan Antara Arah } \\
\text { Kecepatan dan Gaya } \\
\vec{v} \longrightarrow \vec{F} \\
\vec{v} \longrightarrow \vec{F} \text {-List } \\
\vec{v}, \Delta \vec{v} \longrightarrow \vec{F} \\
\vec{v}=0 \rightarrow \vec{F}_{1}\end{array}$ & $\begin{array}{l}1,16 \\
9 \\
7 \\
12\end{array}$ \\
\hline 3. & $\begin{array}{l}\text { Hubungan Antara Arah } \\
\text { Percepatan dan Kecepatan } \\
\vec{a} \longrightarrow \vec{v}, \\
\vec{a} \longrightarrow \vec{v}, \Delta \vec{v} \\
\vec{a} \longrightarrow \Delta \vec{v},\end{array}$ & $\begin{array}{l}4,13 \\
8 \\
15\end{array}$ \\
\hline 4. & $\begin{array}{l}\text { Hubungan Antara Arah } \\
\text { Percepatan dan Gaya } \\
\vec{a} \longrightarrow \vec{F} \text {, }\end{array}$ & 11 \\
\hline 5. & $\begin{array}{l}\text { Hubungan Antara Arah Gaya dan } \\
\text { Kecepatan } \\
\vec{F}=0 \longrightarrow \overrightarrow{v_{1}} \\
\vec{F} \longrightarrow \overrightarrow{v_{1}}\end{array}$ & $\begin{array}{l}3 \\
10,14\end{array}$ \\
\hline 6. & $\begin{array}{l}\text { Hubungan Antara Arah Gaya dan } \\
\text { Percepatan } \\
\vec{F} \longrightarrow \vec{a},\end{array}$ & 5 \\
\hline
\end{tabular}

Berdasarkan hasil penelitian yang telah dilakukan, maka pada penelitian ini diperoleh informasi tentang pemahaman konsep mahasiswa mengenai materi mekanika yang mencakup konsep tentang kecepatan, percepatan dan gaya pada soal FVA berdasarkan hubungan antar konsep:

\subsection{Hubungan antara Arah Kecepatan dan Percepatan}

Tabel II, konsep mengenai hubungan antara kecepatan dan percepatan terdapat pada soal nomor 2, 6 dan 17. Pada soal nomor 6 tentang benda yang bergerak ke arah timur sebagian besar memilih jawaban bahwa percepatan benda ke arah benda bergerak tersebut. Pada mahasiswa semester akhir (angkatan 2010) 94\% menjawab salah. Dari distribusi pemilihan option kebanyakan memilih option a mengalami percepatan ke timur, dengan alasan karena gerobak bergerak ke timur jadi percepatannya juga ke timur. Mereka menyatakan bahwa percepatannya akan kearah timur karena gerobaknya bergerak kearah timur. Responden kurang memahami hubungan arah kecepatan dan arah percepatan. Pada mahasiswa baru (angkatan 2013) 96\% menjawab salah. Dari distribusi pemilihan option kebanyakan memilih option a mengalami percepatan ke timur, dengan alasan karena gerobak bergerak ke timur jadi percepatannya juga ke timur seperti karena gerobak bergerak ke timur jadi percepatannya juga ke timur. Responden yang lain memberikan alasan bahwa kecepatan benda akan sama dengan arah percepatannya.

Mahasiswa semester akhir (angkatan 2010) dan mahasiswa baru (angkatan 2013) samasama memahami bahwa benda yang bergerak maka arah percepatannya akan sama dengan arah geraknya. Karena gerobak bergerak ke timur maka percepatannya juga akan ke timur. Dari alasan yang dikemukakan jawabannya tidak bisa mengalami percepatan ke barat atau tidak mengalami percepatan. Mereka tidak memahami kalau pada saat bergerak kecepatan gerobak mungkin bisa bertambah, berkurang atau konstan. Pernyataan pada soal percepatan gerobak adalah ke timur, sehingga percepatannya juga ke timur. Soal omor 6 seharusnya jawaban yang benar ialah option $f$. Gerobak dapat bergerak dengan kecepatan berkurang, bertambah atau dalam keadaan konstan sehingga gerobak dapat mengalami percepatan ke timur atau ke barat dan juga gerobak dapat tidak mengalami percepatan. Dari alasan yang dikemukakan oleh responden juga dapat dilihat bahwa mahasiswa belum memahami konsep tentang hubungan antara arah kecepatan dan arah percepatan. Mereka hanya memahami ketika benda bergerak maka arah geraknya akan tetap searah dengan percepatannya. Dari wawancara yang telah dilakukan beberapa responden menyatakan bahwa mereka telah mempelajari materi kecepatan dan percepatan tetapi kurang memahami konsep, mereka lebih suka belajar yang berkaitan dengan perhitungan dibandingkan konsep karena memahami hitungan lebih mudah daripada konsep. 


\section{Jurnal Pendidikan Fisika Tadulako (JPFT) \\ Vol. 1 No. 3}

ISSN 23383240

3.2 Hubungan antara Arah Kecepatan dan Gaya

Tabel II, konsep mengenai hubungan antara kecepatan dan gaya terdapat pada soal nomor $1,7,9,12$ dan 16. Pada soal berkaitan dengan hubungan antara arah kecepatan dan gaya dari hasil penelitian yang telah dilakukan diperoleh distribusi pemilihan tiap-tiap option hampir sama dengan hasil penelitian yang telah dilakukan oleh Rosenblatt dan Heckler [2]. Soal nomor 1 tentang sebuah perahu yang bergerak ke utara disebuah danau. Sama halnya penelitian mereka diperoleh distribusi pemilihan option yang terbanyak yaitu option a. Sebuah perahu yang bergerak ke arah utara, dari persentase mahasiswa sebagian besar memilih option a yaitu mungkin ada beberapa gaya ke utara dan ke selatan yang bekerja pada perahu, tetapi gaya ke utara lebih besar. Mereka menyatakan bahwa gaya yang lebih besar adalah gaya yang ke utara karena pada saat itu perahu bergerak ke utara. Mereka hanya melihat dari pernyataan bahwa perahu sedang bergerak ke utara, mereka tidak memahami bahwa perahu bisa saja bergerak dengan kecepatan tertentu. Kecepatan perahu bisa saja berkurang, bertambah ataupun konstan. Kecepatan berkurang bisa saja dengan gaya yang bekerja berlawanan dengan arah gerak perahu tersebut. Kecepatan bertambah pada saat arah gerak perahu searah dengan gaya yang bekerja dan kecepatan konstan pada saat gaya-gaya yang bekerja pada perahu sama besar.

Mahasiswa semester akhir (angkatan 2010) untuk soal nomor 12 tentang bola yang menggelinding ke arah timur berlawanan arah angin dan berbalik arah ke barat searah dengan angin. Dari hasil tes dan wawancara yang dilakukan responden memberikan alasan berdasarkan pernyataan pada soal. Ketika benda bergerak kearah timur dan benda bergerak ke arah barat, merupakan dua kondisi yang sama tetapi berlawanan arah. Sehingga responden cenderung mengaitkan dengan hukum 3 newton atau melihat dari segi matematisnya. Sedangan pada mahasiswa baru (angkatan 2013) untuk soal nomor 12 tentang bola yang menggelinding ke arah timur berlawanan arah angin dan berbalik arah ke barat searah dengan arah angin. Salah satu responden memilih c dengan alasan karena ketika benda berhenti sehingga kecepatannya nol, yang menunjukkan pada saat itu dua gaya yang bekerja adalah sama besar.
Soal nomor 12 ini jawaban yang benar adalah option b gaya yang lebih besar adalah gaya yang searah dengan gerak benda, dengan melihat pernyataan pada saat bola menggelinding ke timur itu melawan angin dan diperlambat dan pada saat berbalik ke arah barat bola dipercepat. Gaya merupakan besaran vector, karena memiliki satuan, besaran, dan arah. Jika sebuah gaya total diberikan pada benda maka kecepatannya akan berubah. Suatu gaya total yang diberikan pada sebuah benda mungkin menyebabkan lajunya bertambah, atau jika gaya total itu mempunyai arah yang berlawanan dengan gerak, gaya tersebut akan memperkecil laju benda itu (Giancoli, 1999). Tetapi dari penjelasan dan hasil wawancara masih banyak juga belum memahami yaitu dengan menghubungkan dengan hukum 3 newton $F_{a k s i}=-F_{\text {reaksi }}$ sehingga memilih option c alasannya dengan melihat bahwa terdapat dua buah gaya yang sama besar bekerja pada benda. Mereka lebih cenderung melihat dari segi matematisnya, pada saat bola bergerak ke timur dan pada saat bola bergerak ke barat.

\subsection{Hubungan antara Arah Percepatan dan Kecepatan}

Tabel II, konsep mengenai hubungan antara arah percepatan dan kecepatan terdapat pada soal nomor 4, 8, 13 dan 15 . Pada soal berkaitan dengan hubungan antara arah percepatan dan kecepatan dari hasil penelitian yang telah dilakukan juga diperoleh distribusi pemilihan tiap-tiap option hampir sama dengan hasil penelitian yang telah dilakukan oleh Rosenblatt dan Heckler [2]. Soal nomor 4 tentang sebuah mobil yang berada disebuah bukit dengan arah percepatan mobil adalah menanjak. Sama halnya penelitian mereka diperoleh distribusi pemilihan option yang terbanyak yaitu option a. Sebuah mobil yang berada dibukit dengan arah percepatan menanjak, dari persentase mahasiswa sebagian besar memilih option a yaitu gerakan mobil adalah bergerak menanjak dengan alasan ketika arah percepataanya menanjak, maka mobil itu juga akan bergerak menanjak karena ketika suatu benda bergerak menanjak otomatis percepatannya menanjak. Dari distribusi jawaban dan alasan yang dikemukakan oleh mahasiswa dapat diketahui bahwa mereka masih belum memahami konsep hubungan antara arah percepatan dan kecepatan. Mobil juga dapat bergerak menurun dengan kecepatan mobil berkurang sehingga arah percepatannya akan tetap menanjak 
ISSN 23383240

sesuai dengan pernyataan pada soal bahwa arah percepatannya menanjak karena kecepatan berkurang akan berlawanan arah dengan percepatannya. Tidak bergerak atau mobil dalam keadaan diam, agar mobil tidak bergerak karena pengaruh gaya gravitasi (percepatan mengarah ke bawah) maka arah percepatan tetap menanjak.

Soal nomor 15 tentang mobil bergerak dengan percepatan menuju utara, sebagian besar memilih jawaban yang mobil dapat bergerak dengan kecepatan meningkat dan kecepatan berkurang dengan alasan jika gaya yang diberikan searah dengan kecepatan maka kecepatan akan meningkat dan jika gaya diberikan berlawanan arah maka kecepatannya akan berkurang. Responden lainnya memilih jawaban yang benar gerak mobil dapat mengalami kecepatan meningkat atau berkurang dengan alasan selama mobil tidak mengalami hambatan maka akan meningkat dan akan berkurang jika ada yang menghambatnya.

Hasil wawancara dengan beberapa responden. diketahui responden kurang memahami hubungan arah percepatan dan arah kecepatan. Ketika ditanyakan tentang hubungan antara kecepatan meningkat dengan arah percepatannya mereka tidak dapat menjelaskan. Dari soal nomor 15 tentang benda yang mengalami percepatan, beberapa responden menyatakan bahwa jika benda mengalami percepatan maka kecepatan benda akan meningkat dan tidak aka nada keadaan dimana kecepatan berkurang. Sebagian responden juga menyatakan bahwa jika kecepatan berkurang, maka benda tidak mengalami percepatan.

Soal nomor 15 responden banyak yang memilih jawaban yang benar yaitu adalah option c yang menyatakan option a dan b adalah mungkin dimana kecepatan mobil dapat meningkat dan berkurang. Dalam soal di nyatakan bahwa percepatan mobil mainan adalah ke utara. Option a yaitu kecepatan meningkat dan option b kecepatan berkurang. Gerak mobil mainan ke arah utara dengan kecepatan meningkat maka percepatannya akan sesuai dengan pernyataan pada soal, percepatannya adalah ke utara. Untuk option b, kecepatan berkurang bisa dengan asumsi bahwa gerak mobil pada saat itu adalah ke arah selatan. Tetapi dari alasan dan wawancara yang dilakukan pada beberapa responden dari tiaptiap angkatan tidak dapat menjelaskan tentang option b kecepatan berkurang. Responden belum memahami ketika benda dengan kecepatan bertambah maka akan searah dengan percepatannya, sedangkan kecepatan berkurang maka akan berlawanan dengan percepatannya.

\subsection{Hubungan antara Arah Percepatan dan Gaya}

Tabel II, konsep mengenai hubungan antara percepatan dan gaya terdapat pada soal nomor 11. Konsep hubungan antara arah percepatan dan gaya yang terdapat pada soal nomor 11 tentang benda yang mengalami percepatan dan dipengaruhi oleh gaya. Soal nomor 11 tentang bola dipercepat ke kanan $72 \%$ menjawab dengan benar, tetapi hanya sebagian yang dapat memberi penjelasan yang benar, mereka hanya menjawab dengan alasan karena benda tersebut dipercepat kearah kanan sehingga gaya yang ke kanan yang lebih besar. Alasan hanya berdasarkan pilihan jawaban yang ada benda mengalami percepatan ke arah kanan jadi meskipun ada gaya ke kiri dan kekanan yang berpengaruh, tetapi gaya ke kanan yang lebih besar. beberapa responden memilih jawaban yang salah, salah satu responden memberikan alasan bahwa percepatan suatu benda akan berbanding terbalik dengan gaya yang bekerja pada benda. Dari wawancara dan alasan yang dikemukakan diketahui responden belum memahami konsep hubungan antara arah percepatan dan gaya, mereka menjawab berdasarkan apa yang ada dipikiran mereka pada saat diberikan tes. Sebelumnya mereka telah mempelajari konsep tentang percepatan dan gaya, tetapi kurang memahaminya dan sebagian tidak tahu.

Pertanyaan nomor 11 yang benar adalah option a mungkin ada beberapa gaya ke kanan dan ke kiri beraksi pada bola, tetapi gaya ke kanan lebih besar. karena di soal dijelaskan bahwa bola bermain adalah dipercepat ke kanan. Ketika ada beberapa gaya yang dikenakan pada sebuah benda maka dapat mempengaruhi gerak benda. Benda akan mengalami percepatan atau perlambatan, benda akan mengalami percepatan ketika resultan gaya yang bekerja pada benda searah dengan gerak benda, sedangkan benda akan mengalami perlambatan ketika resultan gaya yang bekerja pada benda berlawanan arah dengan arah gerak benda.

\subsection{Hubungan antara Arah Gaya dan Kecepatan}


Tabel II, konsep mengenai hubungan antara gaya dan kecepatan terdapat pada soal nomor 3, 10 dan 14. Pada soal berkaitan dengan hubungan antara arah gaya dan kecepatan dari hasil penelitian yang telah dilakukan diperoleh distribusi pemilihan tiap-tiap option hampir sama dengan hasil penelitian yang telah dilakukan oleh Rosenblatt dan Heckler [2]. Dari hasil penelitian mereka mengungkapkan bahwa mahasiswa mengalami miskonsepsi. Soal nomor 3 dari 100 mahasiswa yang termasuk dalam subyek penelitian hanya $4 \%$ menjawab dengan benar, $61 \%$ memilih option c tidak bergerak dengan alasan karena kedua gaya yang berpengaruh adalah sama besar dan berlawanan arah sehingga resultan gayanya adalah sama dengan nol. Dengan resultan gaya yang sama dengan nol maka benda tidak akan bergerak.

Mahasiswa semester akhir (angkatan 2010) dan mahasiswa baru (angkatan 2013) masingmasing hanya $4 \%$ yang dapat menjawab dengan benar pertanyaan nomor 3 tentang permainan tarik tambang antara anjing dan siswa dengan gaya yang sama besar. sebagian besar memilih option c tidak bergerak dengan alasan karena keduanya memiliki gaya yang sama dalam keadaan berlawan arah. Mereka hanya melihat dari segi matematisnya yang dikaitkan dengan hukum 3 newton $F_{a k s i}=-$ Freaksi, sehingga resultan gayanya adalah sama dengan nol. Pada saat resultan gayanya sama dengan nol artinya bahwa tidak akan terjadi pergerakan baik menuju anjing ataupun siswa. Hal ini juga sesuai dengan hasil wawancara yang dilakukan kepada beberapa responden. Seharusnya jawabannya bisa bergerak menuju anjing, bergerak menuju siswa dan juga tidak bergerak. Sesuai dengan hukum gerak Newton pertama yang menyatakan bahwa setiap benda tetap berada dalam keadaan diam atau bergerak dengan laju tetap sepanjang garis lurus, kecuali jika diberi gaya total yang tidak nol (Giancoli, 1999).

Berdasarkan jawaban dan alasan yang dikemukakan oleh responden dapat diketahui bahwa responden belum memahami konsep hubungan antara gaya dan kecepatan. Mahasiswa lebih cenderung ke segi matematis daripada pemahaman konseptual, karena sekalipun mereka pernah mempelajarinya tetapi mereka kurang memahami konsep. Dari penjelasan mereka selama ini kebanyakan mereka diajarkan tentang perhitungan dibandingkan konsep.

\subsection{Hubungan antara Arah Gaya dan Percepatan}

Tabel II, konsep mengenai hubungan antara gaya dan Percepatan terdapat pada soal nomor 5. Konsep hubungan antara arah gaya dan percepatan yang terdapat pada soal nomor 5 tentang sebuah benda yang diberikan gaya. Pada mahasiswa semester akhir (angkatan 2010) untuk soal nomor 5 ini 32\% dan pada mahasiswa baru (angkatan 2013) 44\% memilih option yang benar, dengan alasan karena mobil didorong menuju jalan jadi percepatannya menuju jalan.

Soal nomor 5 tentang mobil yang bergerak menuju jalan karena didorong. Dari hasil wawancara pada salah satu responden memilih a hanya karena mobil menuju jalan sehingga percepatannya ke jalan. Dan dari alasan yang dikemukakan oleh responden dapat diketahui bahwa mereka memilih jawaban percepatan menuju jalan hanya karena mobil di dorong menuju jalan, tanpa memperhatikan bahwa ada gaya-gaya lain yang berpengaruh pada mobil yang semuanya lebih besar mengarah ke jalan.

Pernyataan nomor 5 ini yang benar seharusnya adalah option a yang menyatakan bahwa besar gaya yang berpengaruh sama besar. Percepatannya menuju jalan, karena resultan gaya yang bekerja lebih besar mengarah ke jalan. Dari hasil tes dan wawancara di ketahui bahwa responden masih belum memahami konsep hubungan antara arah gaya dan percepatan. Ketika sebuah benda diberi gaya searah dengan arah gerak benda maka benda akan mengalami pertambahan kecepatan atau mengalami percepatan. Sedangkan ketika benda diberi gaya yang berlawanan dengan gerak benda maka benda akan mengalami pengurangan kecepatan atau perlambatan. Ketika ada beberapa gaya yang bekerja pada benda maka gaya yang akan lebih berpengaruh adalah gaya yang lebih besar. Saat gaya yang lebih besar itu searah dengan gerak benda maka akan mengalami percepatan tetapi kalau berlawanan maka akan mengalami perlambatan. Dari hasil wawancara responden mengungkapkan bahwa masih kurang memahami konsep, meskipun pernah mempelajari konsepnya tetapi belum terlalu memahami.

\section{KESIMPULAN}

Berdasarkan hasil penelitian dengan menggunakan tes hubungan antara arah gaya, kecepatan dan percepatan (Test FVA) dalam 
bentuk pilihan ganda beralasan dan wawancara yang diberikan kepada mahasiswa calon guru fisika, diperoleh gambaran pemahaman mahasiswa sebagai berikut:

1. Hubungan antara arah kecepatan dan percepatan, mahasiswa memahami bahwa ketika suatu benda bergerak maka kecepatannya akan selalu searah dengan percepatannya.

2. Hubungan antara arah kecepatan dan gaya, mahasiswa beranggapan bahwa bola yang bergerak ke arah tertentu dan berbalik arah merupakan dua kondisi yang berbeda. Sehingga mereka cenderung mengaitkan dengan hukum 3 newton.

3. Hubungan antara arah percepatan dan kecepatan, mahasiswa memahami bahwa jika sebuah benda mengalami percepatan maka kecepatannya akan meningkat, kecepatan meningkat ada karena percepatan.

4. Hubungan antara arah percepatan dan gaya, mahasiswa memahami bahwa jika suatu benda dipercepat maka gaya yang bekerja searah dengan percepatannya.

5. Hubungan antara arah gaya dan kecepatan, mahasiswa memahami bahwa ketika sebuah benda dipengaruhi oleh dua buah gaya yang sama besar dan berlawanan arah maka benda tidak akan dapat mengalami pergerakan.

6. Hubungan antara arah gaya dan percepatan, mahasiswa memahami bahwa ketika sebuah benda bergerak dan diberi gaya maka percepatannya akan searah dengan gaya yang diberikan itu.

7. Pemahaman konsep antara mahsiswa baru dan mahasiswa semester akhir tidak menunjukkan perbedaan.

\section{PUSTAKA RUJUKAN}

[1] Sutopo. (2012). Pembelajaran Kinematika Berbasis Diagram Gerak: Cara Baru Dalam Pengajaran Kinematika. Prosiding Seminar Nasional Penelitian, Pendidikan dan Penerapan MIPA,Fakultas MIPA, Universitas Negeri Yogyakarta.

[2] Rosenblatt, R. \& Heckler, A. F. (2011). Systematic study of student understanding of the relationship between the directions of force, velocity, and acceleration in one dimension. PhyRevSTEPER, Volume 7. 02011220 lembar.

[3] Pendrill, A-M. (2007). Acceleration in school, in everyday life and in amusement parks. Department of Physics, Göteborg University, SE-412 96 Göteborg, Sweden. SwePub.

[4] Pujianto, Nurjannah dan I Wayan Darmadi. (2013). Analisis Konsepsi Siswa Pada Konsep Kinematika Gerak Lurus. Ejurnal pendidikan universitas tadulako, Volume 1 no.1. 